УДК 781.65

\title{
Чжсан Тяньтянь,
}

ассистент-стажер кафедры специального фортепиано

Одесской национальной музыкальной академии им. А. В. Неждановой odma_n@ukr.net

\section{КАПРИЧЧИО КАК ПОНЯТИЕ И ЯВЛЕНИЕ}

Цель работы. В статье раскрывается многообразие, а также определяется содержание явления и понятия «каприччио» в музыке, живописи, литературе и кинематографе. Методология исследования заключается в использовании комплексного и историко-теоретического методов, что позволило дать характеристику понятия «каприччио» в различных аспектах, концентрируясь на его этимологии. Научная новизна статьи заключается в расширении представлений о сущности понятия «каприччио», в предложении собственного определения жанра. Выводы. Рассуждения о природе понятия и явления «каприччио» помогают раскрыть его существенные черты, определить его постоянно изменяющийся, вбирающий все новые и новые жанровые свойства характер.

Ключевые слова: каприччио, каприччо, каприз, прихоть, причудливость, фантазия, разные виды искусства, жанр.

Zhang Tientyan, postgraduate student of the department special pianoforte Odessa national Music Academy. A. V. Nezhdanoev

\section{Capriccio as a concept and a phenomenon}

The purpose of work. The article reveals the diversity, and also determines the content of the phenomenon and the concept of «capriccio» in music, painting, literature and cinema. The methodology of the study consists in the use of complex and historical-theoretical methods, which made it possible to characterize the concept of «capriccio» in various aspects, concentrating on its etymology. The scientific novelty of the article is to expand the notion of the essence of the concept of «capriccio», in the proposal of own definition of the genre. Conclusions. The reasoning about the nature of the concept and the phenomenon of «capriccio» helps to reveal its essential features, to determine its constantly changing character, which is taking on more and more genre properties.

Keywords: capriccio, capriccio, whim, whim, whimsicality, fantasy, different kinds of art, genre.

Чжан Тяньтянь, асистент-стажист кафедри спеціального фортепіано Одеської національної музичної академії ім. А. В. Нежданової

\section{Капричіо як поняття та явище}

Мета роботи. У статті розкривається різноманіття, а також визначається зміст явища і поняття «капричіо» в музиці, живописі, літературі та кінематографі. Методологія дослідження полягає у ви- 
користанні комплексного та історико-теоретичного методів, що дозволило дати характеристику поняття «капричіо» в різних аспектах, кониентруючись на його етимології. Наукова новизна статті полягає в розширенні уявлень про сутність поняття «капричіо», в пропонуванні власного визначення жанру. Висновки. Міркування про природу поняття і явища «капричіо» допомагають розкрити його істотні риси, визначити його характер, що постійно змінюється, вбираючи все нові й нові жанрові властивості.

Ключові слова: капричіо, капричо, каприз, примха, примхливість, фантазія, різні види мистецтва, жанр.

Каприччио (каприччо) - чрезвычайно интересный жанр, прошедший длительный исторический путь развития и относящийся к различным видам искусств. Обратимся к этимологическому анализу жанра музыкального произведения - каприччио. Рассмотрим его с позиции понимания понятия и явления, используя различные энциклопедические, словарные, музыковедческие и другие источники. А затем, проанализировав все дефиниции и исторические варианты существования жанра каприччио, дадим его собственное определение. Но на данном этапе исследования ограничимся определением каприччио (каприччо) относительно музыкальных жанров.

Название жанра каприччио происходит от итальянского слова capriccio, что переводится как каприз, прихоть, причудливый изыск. Синонимами являются слова «каприс» (французское произношение итальянского «каприччио»), capriccio (ит. каприччо, традиционное произношение каприччио), сарrice (фр. каприс) - каприз, прихоть; capricciosamente (ит. каприччозамэнтэ), capriccioso (каприччозо), capricieusement (фр. каприсьезман), сарricieux (каприсье) - причудливо, капризно [8, 211]. Каприччо, каприччио (итальянский capriccio, множественное число - каприччи), также каприс (французское caprice) - данный термин чаще всего обозначает инструментальную пьесу свободной формы, созданную в блестящем виртуозном стиле. Для многих в музыкальном искусстве каприччо воспринимается как причудливая смена эпизодов, настроений. Расцвет данного жанра приходится на эпоху романтизма.

Доверимся наиболее старинным источникам, например, словарю Г. Римана (мы позволили себе расшифровывать сокращенные слова в предлагаемых текстах). «Сарriccio (итал., произносится - причьо; франц. Caprice, произносится - прись, «капризъ»), по Преториусу (1618) - синоним Fantassia для фугообразных инструментальных 
пьес; в настоящее время название это не обусловливает определенной формы, а только указывает на то, что пьеса ритмически пикантна и вообще изобилует оригинальными, неожиданными оборотами. Вследствие этого Capriccio трудно отличить от Scherzo. Пьесы, подобные Scherzo b-moll Ф. Шопена, могли бы с одинаковым правом быть названы Capricci. A capriccio - то же, что ad libitum (по усмотрению исполнителя, не следуя строго указаниям автора)» [6, 595]. Так по Г. Риману каприччио = фантазии $=$ скерцо.

В сокращенном 18-м издании энциклопедии Ф. Брокгауза и И. Ефрона понятие «каприччио» формулируется кратко и конкретно, но несколько иначе: «Каприччио (Capriccio) - музыкальное сочинение, не имеющее определенной формы, близкое к скерцо, но с неожиданными уклонениями, пишется для отдельных инструментов и для оркестра» [3, 270].

М. Рыцарева говорит, что каприс означает каприз. Хотя это слово мы обычно произносим с негативным оттенком, ничего недостойного для музыкального искусства в нем нет. Наоборот, оно означает свободный, как сама природа, полет творческой мысли, сопоставление ярких красок и неожиданных светотеней, сочетание праздничной виртуозности и задумчивой меланхолии [13].

А вот как считает Гроуве: «Каприччио (каприччио, итал. capriccio «прихоть», «каприз»; франц. эквивалент - каприс, сарrice) - это жанровое обозначение относится преимущественно к виртуозным одночастным или многочастным инструментальным произведениям свободной структуры. Среди наиболее известных образцов органные и клавирные Каприччио мастеров барокко: Д. Фрескобальди, И. Фробергера, Я. Свелинка, И. С. Баха; фортепианные Каприччио Й. Брамса, скрипичные Каприччио («каприсы») Н. Паганини, оркестровые Каприччио («каприччио») П. Чайковского и Н. РимскогоКорсакова. В XVIII веке термином «каприччио» иногда обозначались импровизируемые каденции [4, 383].

Жанр каприса (каприччио) весьма старинный, так как это понятие известно с XVI века. Но трудно себе представить, сколь неожиданным, многогранным и «капризным» был его исторический путь.

Увлечение инструментальными Каприччо, а также различного рода «фантазиями» и всевозможными stravaganza, то есть «необычностями», «своеобразностями», было в XVII-XVIII веках всеобщим. Композиторы того времени как бы подчеркивали, что им особенно близки творческая фантазия, озарение, внезапные находки, выдумки. 
Применительно к музыке подразумевалась при этом возможность нарушения строгих правил контрапункта. На это указывают, в частности, замечания Джироламо Фрескобальди в предуведомлении к сборнику своих каприччио, который появился в 1624 году - «12 каприччио» для органа. Это блестящие виртуозные полифонические пьесы, в которых подразумевались (и широко использовались композитором) нарушения строгих правил контрапункта. Причем в своей ремарке автор требует от органиста «огня в исполнении».

Термин каприччио применялся для разных жанров, использующих различные формы, как вокальные, так и иные исполнительские составы. Наиболее раннее применение термина встречается в 1561 году и относилось к собранию мадригалов [16]. В музыке XVI века к жанру каприччио относились многоголосные вокальные пьесы типа мадригала. Таким образом, появилось еще одно значение понятия каприччио:

\begin{tabular}{|c|c|c|c|c|}
\hline \multicolumn{5}{|c|}{ Каприччио = многоголосная пьеса типа мадригала } \\
\hline \multicolumn{5}{|c|}{$\begin{array}{l}\text { В начале XVII века так стали называть и разнообразные инстру- } \\
\text { кентальные полифонические пьесы, часто имитационного склада, со } \\
\text { вободной формой построения (типа ричеркара, канцоны, фантазии) }\end{array}$} \\
\hline \multicolumn{5}{|c|}{ РАЗНОВИДНОСТИ ЖАНРА КАПРИЧЧИО В НАЧАЛЕ ХVІІ ВЕКА } \\
\hline Ричеркар & Канцона & Фантазия & Прелюдия & Токката \\
\hline \multicolumn{5}{|c|}{ Полифонические пьесы часто имитационного склада } \\
\hline & & & & \\
\hline
\end{tabular}

В 1618 году М. Преториус определил Каприччо как свободную, импровизируемую фантазию, не связанную с какой-либо предустановленной обязательной схемой развития тематического материала. Таким образом, здесь:

$$
\text { КАПРИЧЧИО = имПровизационная фантазия }
$$

Еще более «свободными» по строению стали «Причудливые каприччио» для скрипки соло К. Фарина (1627) - это программно-изобразительные жанровые пьесы-сценки в народном духе, с широким применением звукоизобразительности, даже с использованием приемов натуралистического звукоподражания.

$$
\text { КАПРИЧЧИО = }
$$

музыкальные программно-изобразительные жанровые сценки

в народном духе 
Наиболее оригинальное и широко известное произведение молодого И. С. Баха (написано в ранний период творчества композитора) - «Каприччио на отъезд возлюбленного брата» (1704 или 1705 г.), где речь идет о приближающемся отъезде Иоганна Якоба Баха. Это программное сочинение для клавира, образцом для которого, видимо, послужили незадолго до того опубликованные «Библейские сонаты» Иоганна Кунау в 1700 году (начал писать данные сонаты для клавира в 1692 году).

Приведем слова Ромена Роллана относительно предшественника И. С. Баха: «Библейские сонаты», как и некоторые другие пьесы Кунау, дают основание считать его «не только прямым предшественником Иоганна Себастиана Баха... но, судя по многим местам, и безусловным для него образцом» $[12,150]$. Кунау один из первых применил для клавира форму циклической сонаты, заимствовав ее из скрипичной литературы; затронул в клавесинной музыке более сложную сферу образов и чувств, нуждающихся в новых средствах музыкального воплощения. В этом И. Кунау вплотную приблизился к И. С. Баху, предвосхищая содержание его творчества.

Программное «Каприччо на отъезд возлюбленного брата» И. С. Баха - циклическое произведение, которое представляет собой, в сущности, старинную сонату (напомним, что в понимании этого жанра XVII века старинная соната воспринималась как цикл пьес нетанцевального характера). В «Каприччио на отъезд возлюбленного брата» - несколько частей, причем каждая из них снабжена программным заголовком. Кончается данное Каприччио фугой, звукоизобразительно имитирующей рожок почтальона.

B Каприччио (Capriccio brillant для фортепиано с оркестром h-moll op. 22, созданном в 1832 году Мендельсоном) предугадываются черты зрелого И. С. Баха, особенно в третьей части - чаконе, наделенной подзаголовком «Всеобщая скорбь друзей» (сравним с кантатой № 12) $[2,28]$.

K середине XVIII века название жанра каприччио стало использоваться по-иному - для каденций, особенно сочиняемых самими композиторами. Считается, что именно эти виртуозные каденции стали прототипом романтического каприччио, смысл которого сместился в сторону изломанности, салонности, «виртуозного изыска» сочинения.

П. Локателли (автор «Искусство скрипки», 1733 г.), как и другие скрипачи XVIII века, понимал Каприччо как импровизируемую каденцию, позволяющую исполнителю показать богатство своей музы- 
кальной фантазии. К такой трактовке Каприччо позднее склонялся и В. А. Моцарт.

\section{КАПРИЧЧИО = импровизированная виртуозная каденция}

В этом отношении важными прецедентами стали каденции-каприччио Пьетро Локателли к его 12 скрипичным концертам (1732). Поскольку такие каденции носили виртуозный характер, в эпоху романтизма акцент в жанровом обозначении «каприччио» сместился в сторону «виртуозного изыска» сочинения, - в этом смысле наиболее показательны «24 каприса для скрипки соло» Николо Паганини. Новое ощущение мира, природы, явившееся неожиданным для самих композиторов «открытием», отражено в самом названии «каприччо». В начале XIX века Н. Паганини в своих «24 каприччи для скрипки соло» ор. 1 вдохнул в форму Каприччо новое содержание, создав художественные произведения, в которых поле фантазии и «игра трудностями» сочетаются с богатством музыкальной мысли.

Более классические по звучанию и форме воплощения - скерцозные каприччио Й. Гайдна, острохарактерные пьесы Л. Бетховена. В эпоху классицизма жанр каприччио принадлежал обычно к инструментальной музыке

XIX век дал множество образцов жанра каприччио. Наиболее яркие из них: «Блестящее каприччио» для фортепиано с оркестром $Ф$. Мендельсона (1832), каприччио на тему арагонской хоты (позднее названная просто «Арагонская хота») М. Глинки (1845); «Итальянское каприччио» П. Чайковского (1880); «Испанское каприччио» Н. Римского-Корсакова (1887); «Арабское каприччио» и «Интродукция и рондо-каприччиозо» К. Сен-Санса; целый ряд сочинений данного жанра Й. Брамса; всемирно известные «24 каприса для скрипки соло» Н. Паганини; произведения К. М. Вебера, М. Регера, А. Дворжака, Г. Венявского. Эпоха романтизма развивала и акцентировала порывистую, мятущуюся, стихийную сущность каприччио, неожиданные и резкие сопоставления тематизма, его романтический порыв и свободу формы.

В энциклопедии Брокгауза и Ефрона отмечается, что «Каприччио (capriccio - ит.) - каприз, музыкальное сочинение, в котором автор не подчиняется установившимся формам, а слагает его по своей фантазии» [3]. Они отмечают, что в Каприччио «темы оригинальные, резко индивидуальные, контрастирующие. Каприччио пишут для сольного инструмента, а также для оркестра. В первом случае Каприччио 
нередко имеет форму этюда, в котором проводится один мотив с резким очертанием или в виде виртуозной пьесы (Capriccio Ф. Мендельсона для фортепиано с оркестром, ор. 22); во втором случае в Каприччио встречаются несколько контрастирующих тем...» [3, 270].

А. Должанский считает, что «Каприччио, каприччо (ит. capriccio каприз, прихоть) - пьеса, обычно виртуозная, капризного, причудливого характера, свободного построения, то же, что каприс (фр. caprice). Часто в основу Каприччио композиторы кладут народные мелодии» $[1,114]$. Аналогичное определение мы встречаем в Словаре иностранных слов: Капричч(и)о (ит. сарriccio) - иначе каприс - музыкальная инструментальная пьеса свободного построения, виртуозного характера, в блестящем, эффектном стиле, изобилующая неожиданными оборотами, эффектами [7, 219].

Несколько иначе, с исторической точки зрения, подходит к определению Т. Попова. По ее мнению, каприччио или каприс - в XVIII и начале XIX века - название инструментальной пьесы, нередко остро ритмованной, изобилующей неожиданными и своеобразными оборотами и сопоставлениями. Программное каприччио И. С. Баха «На отъезд возлюбленного брата» (написанное на случай) представляет маленький цикл разнохарактерных пьес [11].

Некоторые каприччио XIX века также связаны со свободной циклической формой: таково знаменитое оркестровое «Испанское каприччио» Н. Римского-Корсакова, «Итальянское каприччио» П. Чайковского, а также «Каприччио на цыганские темы» С. Рахманинова. В большинстве случаев, однако, каприччио оказывается названием сравнительно небольшой инструментальной пьесы (Ф. Мендельсон, М. Балакирев, Й. Брамс). Знаменитые 24 каприса Н. Паганини (широко известные и в виртуозных переложениях для фортепиано Р. Шумана и Ф. Листа) близки к типу этюда; некоторые из них имеют подзаголовки: «Охота», «Кампанелла», («Колокольчики»). Интересно «Каприччио на темы русских народных песен» для фортепиано в четыре руки молодого М Глинки [11, 269].

В другом источнике - у С. Штейнпресса и И. Ямпольского в Энциклопедическом музыкальном словаре - понятие каприччио аналогично, близко предыдущему. Каприччио, правильнее каприччо (итал. capriccio, букв. - каприз, прихоть; мн.ч. каприччи), также каприс (франц. caprice) - инструментальная пьеса свободного построения, виртуозного характера, в блестящем, эффектном стиле. Для многих Каприччо характерна частая «капризная» смена настроений, неожи- 
данность оборотов. В полифонической музыке XVI-XVII веков подобные произведения называются ричеркар, фантазия. Встречались и вокальные Каприччио. Нередко Каприччио - виртуозный этюд; таковы 24 каприччи для скрипки соло Н. Паганини (в обработке Ф. Листа и Р. Шумана для фортепиано они названы этюдами). Каприччио для фортепиано писали Ф. Мендельсон, Й. Брамс и др. образцы в симфонической музыке - «Испанское каприччио» Н. Римского-Корсакова, «Итальянское каприччио» П. Чайковского [14, 213].

Таким образом, в клавирной и фортепианной музыке развитие жанра шло от программного «каприччо» И. С. Баха, скерцозных каприччи И. Гайдна и Л. Бетховена к характерным фортепианным пьесам К. М. Вебера, Ф. Мендельсона, И. Брамса, М. Регера, А. Дворжака.

И. Ямпольский считает, что «в оркестровой музыке XIX века Каприччио, подобно фантазии и рапсодии, является пьесой с ярко выраженной национальной окраской музыкального материала («Итальянское каприччио» П. Чайковского, «Испанское каприччио» Н. Римского-Корсакова, «Арабское каприччио» К. Сен-Санса и др.» $[15,710]$. Близкое фантазии «Каприччо на цыганские темы» С. Рахманинова отмечено национальным колоритом, своенравными переменами движения, оркестровым блеском [5, 236]. Как видим, в определениях много общего, каждый раз с добавлением некоторых уточнений (см. также в «Универсальном энциклопедическом словаpe» $[10,340])$.

В дальнейшем в скрипичной литературе Каприччио приближается к этюду (Р. Крейцер, П. Роде и др.), скерцо. Таким образом, добавляется еще два понимания этого понятия:

\section{Каприччио = этюды, скерцо}

В XX веке данный жанр, каприччио, также встречается в музыке: например, Каприччио для фортепиано с оркестром И. Стравинского; инструментальные каприччио В. Гаврилина, А. Белошицкого, А. Сташевского, А. Кофанова; опера Рихарда Штрауса «Каприччио». В последнем сочинении - одноактной опере - символически представлен извечный спор поэтов и музыкантов: чье искусство важнее? Что важнее в опере - слово или музыка? И выбор должна сделать капризная красавица графиня Маделена, отдав свое сердце одному из поклонников - поэту или музыканту. Но опера так и заканчивается без ответа на данный вопрос. 


\section{Каприччио = опера}

Так постепенно понятие каприччио распространилось и стало использоваться в различных жанрах: от отдельных пьес до опер; сохраняя при этом содержательную нагрузку - шаловливость, игривость, капризность, неожиданную интригу сопоставлений контрастов.

Обратимся к другим видам искусств. Само слово «каприччио» использовалось уже в XVI веке в разных видах искусства. Например, в живописи - это был жанр пейзажа, где изображались архитектурные фантазии, в основном руины вымышленных античных сооружений. Жанр «каприччио» достиг совершенства в полотнах Джованни Паоло Панини (интересное совпадение - фамилия в какой-то степени созвучна величайшему мастеру музыкальных каприсов Паганини).

В теории живописи в более широком смысле термин «каприччио» может обозначать фантастические картины вообще: например, «Varicapricci» - «Разнообразные причуды» Дж. Тьеполо; знаменитая серия офортов Ф. Гойи «Капричос»).

Широко встречается также жанр каприччио в литературе и кино. Например, у Александра Логинова в сборнике рассказов «Итальянское каприччо» или в кино - комедия 1968 года «Итальянское каприччио», решенная в виде ряда новелл, режисерами Марио Моничелли, Стено, Мауро Болоньини, Пьером Паоло Пазолини, Пино Заком, Франко Росси.

Но вернемся к музыке. Что же такое музыкальное каприччио как жанр? Каприччио (capriccio) или каприз (caprice) представляет собой небольшую, «капризную», противоречивую по характеру, быструю, виртуозную инструментальную пьесу (для инструмента-соло или оркестра), часто программного содержания (скрытого или явного); обычно довольно свободную по форме; насыщенную неожиданными (гармоническими, ритмическими, фактурными, содержательными) оборотами и сопоставлениями, с возможным острым, пикантным ритмом и синтезирующую разные жанровые признаки.

\section{СПИСОК ЛИТЕРАТУРЫ}

1. Должанский А. Н. Каприччио. Краткий музыкальный словарь. 6-е изд., испр. СПб.: Издательство «Лань», 2003. С. 114.

2. Друскин М. С. Иоганн Себастиан Бах. М.: Музыка, 1982. 383 с.

3. Каприччио / Брокгауз Ф. А., Ефрон И. А. Энциклопедический словарь: Современная версия. М.: Экспо, 2002. Т. 86.С. 270. 
4. Каприччио / Гроув Музыкальный словарь. Второе русское издание, испр. и доп.. пер. с англ.. М.: Практика, 2007. С. 383.

5. Каприччио. Музыкальный энциклопедический словарь / гл. ред. Г. В. Келдыш. М.: Советская энциклопедия, 1990. С. 236.

6. Каприччио / Риман Г. Музыкальный словарь / перевод и все дополнения под ред. Ю. Энгеля ; перевод с 5-го немецк. издания. Москва-Лепциг: Б. Юргенсона, 1896. С. 595.

7. Капричч(и)о. Словарь иностранных слов. Изд. 18-е, стереотипное. М.: Русский язык, 1989. С. 219

8. Каприччио / Т. С. Крунтяева, Н. В. Молокова, А. М. Ступель. Словарь иностранных музыкальных терминов: 5-е изд.. Л.: Музыка, 1985. С. 211.

9. Каприччио. Википедия.. URL: http: //ru.wikipedia.org/wiki.

10. Каприччио. Универсальный энциклопедический словарь. М.: Научное издательство «Большая российская энциклопедия, 1999. С. 340.

11. Попова Т. Каприччио. Музыкальные жанры и формы. М.: Государственное музыкальное издательство, 1954. 384 с.

12. Ромен Роллан. Музыкальные путешествия в страну пришлого. Собрание починений. Л.: Художественная литература, 1935. Т. XVII. С. 150.

13. Рыцарева М. Г. Каприччио. URL: http://www.classic-music.ru/capriccio. html

14. Штейнпресс Б. С. и Ямпольский И. М. Каприччио. Энциклопедический музыкальный словарь. Изд. 2-е, испр. и доп. М.: Советская энциклопедия, 1966. С. 213.

15. Ямпольский И. М. Каприччо. Музыкальная энциклопедия в 6 m. / гл. ред. Ю. В. Келдыш. М.: Сов. энциклопедия, 1974. Т. 2 : ГОНД-КОРСОВ. C. 710 .

16. Stanley Sadie. The New Crove Dictionazy of Music and Musicians. Crove's Dictionares of Music Ins., 1995. Вып. 3. 2103 p.

\section{REFERENCES}

1. Dolzhansky A. N. (2003) Capriccio. Concise Dictionary of Music. St. Petersburg: Izdatelstvo «Lan», 114 [in Russian].

2. Druskin M. S. (1982) Johann Sebastian Bach. Moskow: Muzyka [in Russian].

3. Capriccio (2002) / Brockhaus FA, Efron IA Encyclopaedic dictionary: The modern version. M.: Expo, 2002. T. 86.270. [in Russian].

4. Capriccio (2007) / Grove Music dictionary. Moskow: Praktika, 383 [in Russian].

5. Capriccio (1990). Music Encyclopedic Dictionary / gl.ed G. V. Keldyish. Moskow: Sovetskaya entsiklopediya, 236[in Russian].

6. Capriccio (1896) / Riman G. Music dictionary. Moscow-Leipzig: Yurgenson, 595 [in Russian].

7. Capricc(i)o (1989) Dictionary of foreign words. Moskow: Russkiy yazyk, 219 [in Russian]. 
8. Capriccio (1985) / T. S. Kruntyaeva, N. V. Kulikova, A. M. Stupel Dictionary of foreign musical terms. Leningrad: Muzyka, 211 [in Russian].

9. Capriccio. Wikipedia. Retrieved from: http://ru.wikipedia.org/wiki [in Russian].

10. Capriccio (1999) Universal Encyclopedic Dictionary. Moscow: Nauchnoe izdatelstvo «Bolshaya rossiyskaya entsiklopediya, 340 [in Russian].

11. Popova T. (1954) Capriccio. Musical genres and forms. Moscow: Gosudarstvennoe muzykalnoe izdatelstvo, 269 [in Russian].

12. Romain Rolland (1935). Musical journey into the past to. Collected works. Leningrad: Hudozhestvennaya literatura. Vols. XVII, 150 [in Russian].

13. Rytsareva M. G. Capriccio. Retrieved from: http://www.classic-music.ru/ capriccio.html [in Russian].

14. Shteynpress B. S. and Yampolsky I. M. (1966). Capriccio. Encyclopedic Dictionary of Music. Moskow: Sovetskaya entsiklopediya, 213 [in Russian].

15. Yampolsky I. M. (1974). Capriccio. Music encyclopedia/gl.ed G. V. Keldyish. Moskow: Sovetskaya entsiklopediya. Vols. 2: GOND-KORSOV, 710 [in Russian].

16. Stanley Sadie (1995). The New Grove Dictionary of Music and Musicians. Grove's Dictionares of Music Ins. Vols. 3 [in English].

Стаття надійшла до редакції 08.06.2016 